\title{
Time Is Like a Clock in My Heart: Implications for Stem Cell Delivery after Myocardial Infarction
}

\author{
John A. Schoenhard ${ }^{a}$ Antonis K. Hatzopoulos ${ }^{b}$ \\ a Division of Cardiovascular Medicine, Department of Medicine, Stanford University, Stanford, Calif., and \\ ${ }^{b}$ Division of Cardiovascular Medicine, Department of Medicine and Department of Cell and Developmental Biology, \\ Vanderbilt University, Nashville, Tenn., USA
}

For more than 2 decades, advances in cardiovascular medicine have trended toward the early detection and treatment of ischemic heart disease. New biomarkers, imaging modalities, and educational campaigns now target at-risk patients for primary prevention. Improved drugs, devices, and healthcare delivery systems speed the reperfusion of thrombosed arteries. Nonetheless, some patients still miss this early detection and treatment window, presenting either late to outlying centers or with pathophysiologic barriers to reperfusion. This missed opportunity may then be followed by scarring, negative remodeling, and heart failure.

Stem cell therapy may change the trajectory of such patients, but it may also require a change in our traditional thinking about optimal treatment timing. While myocardial infarction survivors with systolic dysfunction may benefit from early and ongoing medical therapy with antiplatelets, $\beta$-blockers, ACE inhibitors, aldosterone antagonists, and statins, stem cell therapy may be effective only within a narrow time frame. Stem cell survival may be compromised early after infarction by inflammation, microvascular obstruction, and reperfusion injury. Stem cell homing may be compromised late after infarction by scar formation and cytokine downregulation. Identification of the optimal time for stem cell delivery thus represents a critical piece in the overall cardiac stem cell therapy puzzle [1].

\section{KARGER}

Fax +41613061234 E-Mail karger@karger.ch www.karger.com
() 2010 S. Karger AG, Basel

www.karger.com/crd
In a recent issue of Cardiology, Dr. ter Horst [2] reviews the knowns and unknowns of stem cell timing. We already know that repair after myocardial infarction follows a natural history with prescribed times for intrinsic progenitor cell mobilization [3] and cy tokine/growth factor expression [2, table 1]. We already know that extrinsic stem cell delivery at different times following myocardial infarction yields different outcomes in preclinical [4] and clinical studies [2, table 2]. What we don't know is how best to apply this knowledge to provide optimal stem cell therapy.

In the adjacent table 1, we propose a framework to discuss the implications of stem cell timing and stem cell characteristics for the overall goals of stem cell therapy after myocardial infarction. Extrinsic stem cell delivery may occur either coincident with or distinct from the natural peak in mobilization of intrinsic stem cells of similar lineage. In addition, the pool of cells delivered at any given time may be enriched for specific lineages via cell sorting and expansion techniques or enhanced by hypoxic preconditioning, biological or chemical pretreatment, or gene transfer.

These methodological choices imply different goals of therapy. In the most straightforward scenario, a pool of cells enriched for a specific lineage is delivered coincident with the natural peak in circulating levels of that cell lineage in order to augment the natural healing process (sce-

Antonis K. Hatzopoulos

Department of Medicine, Division of Cardiovascular Medicine, Vanderbilt University MRB IV P425C, 2213 Garland Avenue

Nashville, TN 37232 (USA)

E-Mail antonis.hatzopoulos@vanderbilt.edu 
Table 1. Goals of stem cell therapy after myocardial infarction implied by the timing of stem cell delivery and characteristics of donor cells

\begin{tabular}{l|lll}
\hline \multicolumn{2}{l}{} & \multicolumn{2}{c}{ Timing of extrinsic stem cell delivery } \\
\cline { 3 - 4 } & & $\begin{array}{l}\text { Coincident with peak intrinsic } \\
\text { stem cell mobilization }\end{array}$ & $\begin{array}{l}\text { Distinct from peak intrinsic } \\
\text { stem cell mobilization }\end{array}$ \\
\hline $\begin{array}{l}\text { Extrinsic stem } \\
\text { cell characteristics }\end{array}$ & $\begin{array}{l}\text { Enriched } \\
\text { Enhanced }\end{array}$ & $\begin{array}{l}\text { (A) augment healing } \\
\text { (C) augment and improve healing }\end{array}$ & $\begin{array}{l}\text { (B) extend healing } \\
\text { (D) extend and improve healing }\end{array}$ \\
\hline
\end{tabular}

nario A). Alternatively, the same pool of cells is delivered at an earlier or later time point in order to extend the healing process (scenario B). Scenario A benefits from our faith in the purposeful construction of the human body, whereby myocardial engraftment, survival, and proliferative factors are expressed in harmony with cognate receptors on circulating cells. Scenario B suggests the possibility that beneficial myocardial receptors may be expressed but underoccupied before or after the peak mobilization of their associated cellular targets.

This is the level of complexity of all past and present clinical trials of stem cell therapy after myocardial infarction [5]. Whether by intent or by happenstance, published reports describe scenario A or B or span both, without a prespecified comparison. Post hoc analyses such as those summarized by Dr. ter Horst [2] form our current knowledge base concerning therapeutic timing. Thus far, the delivery of bone marrow-derived stem cells within $24 \mathrm{~h}$ of reperfusion has failed to show benefit [6], indicating that earlier is not always better. Improved outcomes at later time points [2, table 2] are consistent with observed fluctuations in circulating levels of native progenitor cell lineages between 3 and 28 days after myocardial infarction [3].

Within this window, 3 ongoing, multicenter, randomized, controlled trials aim to identify the optimal time for the delivery of bone marrow mononuclear cells after myocardial infarction. The NIH Cardiovascular Cell Therapy Research Network's (CCTRN) TIME trial (http://www.cctrn.org) will compare an early time point of 3 days after infarction to an intermediate time point of 7 days after infarction [7]. A related study called LateTIME will focus on a late time point of 2-3 weeks after infarction using an otherwise identical protocol [8]. The SWISS-AMI study will compare an intermediate time point of 5-7 days after infarction to a late time point of 3-4 weeks after infarction [9]. While these studies may clarify the optimal time for the delivery of bone marrow mononuclear cells, similar time comparator studies may be required for other cell types and other cell preparations.

Stem cells with enhanced functionality, conferred ex vivo by hypoxic preconditioning, biological or chemical pretreatment, or gene transfer, delivered coincidently with the natural mobilization of intrinsic stem cells of similar lineage may not only increase the total number of stem cells available for myocardial repair but also improve the engraftment, survival, and cardioprotective activities of both donor and host cells (scenario C). When delivered at a time otherwise unfavorable for intrinsic stem cell-mediated repair mechanisms, enhanced stem cells may additionally extend the window of opportunity for myocardial repair by providing the necessary paracrine factors $[10,11]$ to allow healing at a time when more deleterious processes might otherwise dominate (scenario D). Indeed, if scenario A represents the goal of current clinical trials, scenario D certainly represents where we will want to be going in the coming years.

To this end, it is imperative that we identify those factors that define the window of opportunity for stem cellmediated repair after myocardial infarction. A catalog of relevant cytokines is provided in the accompanying article by Dr. ter Horst [2, table 1]. Of these, several have been used successfully in rodent models of cell-based gene therapy after myocardial infarction, including homing factors such as stromal cell-derived factor-1 (SDF-1) [12] and vascular endothelial growth factor [13] as well as cell surface markers such as SDF-1's binding partner chemokine (c-X-c motif) receptor 4 (CXCR4) [14] and monocyte chemotactic protein-3's (MCP-3) binding partner chemokine (c-c motif) receptor 1 (CCR1) [15]. These examples demonstrate that cytokine-overexpressing donor cells may provide trophic support to injured myocardium while improving donor and host cell homing. Chemokine receptor-overexpressing donor cells may allow for stem cell retention in injured myocardium at time points with 
a mismatch between myocardial chemokine expression and host stem cell chemokine receptor expression. Together, such strategies may open the temporal window of opportunity for myocardial repair.

The scale-up of enhanced stem cell technologies from mouse to man will be challenging. Although the fundamental biology of myocardial repair is remarkably similar across species, the time course of myocardial repair after infarction is different. Genes that are upregulated within days of a murine myocardial infarction may not be upregulated until weeks after a human myocardial infarction [2, table 1]. Difficult decisions will need to be made. Should stem cells modified to overexpress proteins be delivered in synchrony with the peak native expression (scenario C) or when the corresponding native proteins are lacking but their matching binding partners are maximal (scenario D)? Are the time courses employed in preclinical models helpful in making this decision? The answers to these and other time-critical questions will need to be agreed upon before committing resources to advanced clinical trials. Nevertheless, with continued research, we are confident that stem cell therapy will ultimately reduce the morbidity and mortality of patients with cardiovascular disease.

\section{Acknowledgements}

This work was supported by NIH grants HL083958 and HL087403. The title is from Culture Club's second Top 10 hit song.

\section{References}

1 Schoenhard JA, Hatzopoulos AK: Stem cell therapy: pieces of the puzzle. J Cardiovasc Transl Res 2010;3:49-60.

$\checkmark 2$ ter Horst KW: Stem cell therapy for myocardial infarction: are we missing time? Cardiology 2010;117:1-10

-3 Wang Y, Johnsen HE, Mortensen S, Bindslev L, Ripa RS, Haack-Sørensen M, Jørgensen E, Fang W, Kastrup J: Changes in circulating mesenchymal stem cells, stem cell homing factor, and vascular growth factors in patients with acute ST elevation myocardial infarction treated with primary percutaneous coronary intervention. Heart 2006;92:768774.

4 Ma J, Ge J, Zhang S, Sun A, Shen J, Chen L, Wang K, Zou Y: Time course of myocardial stromal cell-derived factor 1 expression and beneficial effects of intravenously administered bone marrow stem cells in rats with experimental myocardial infarction. Basic Res Cardiol 2005; 100:217-223.

$\checkmark 5$ Boudoulas KD, Hatzopoulos AK: Cardiac repair and regeneration: the Rubik's cube of cell therapy for heart disease. Dis Model Mech 2009;2:344-358.

-6 Zhang S, Sun A, Xu D, Yao K, Huang Z, Jin $\mathrm{H}$, Wang K, Zou Y, Ge J: Impact of timing on efficacy and safety of intracoronary autologous bone marrow stem cell transplantation in acute myocardial infarction: a pooled subgroup analysis of randomized controlled trials. Clin Cardiol 2009;32:458-466.
7 Traverse JH, Henry TD, Vaughan DE, Ellis SG, Pepine CJ, Willerson JT, Zhao DXM, Piller LB, Penn MS, Byrne BJ, Perin EC, Gee AP, Hatzopoulos AK, McKenna DH, Forder JR, Taylor DA, Cogle CR, Olson RE, Jorgenson BC, Sayre SL, Vojvodic RW, Gordon DJ, Skarlatos SI, Moyé LA, Simiari RD, Cardiovascular Cell Therapy Research Network: Rationale and design for TIME: a phase II, randomized, double-blind, placebo-controlled pilot trial evaluating the safety and effect of timing of administration of bone marrow mononuclear cells after acute myocardial infarction. Am Heart J 2009; 158:356-363.

-8 Traverse JH, Henry TD, Vaughan DE, Ellis SG, Pepine CJ, Willerson JT, Zhao DX, Simpson LM, Penn MS, Byrne BJ, Perin EC, Gee AP, Hatzopoulos AK, McKenna DH, Forder JR, Taylor DA, Cogle CR, Baraniuk S, Olson RE, Jorgenson BC, Sayre SL, Vojvodic RW, Gordon DJ, Skarlatos SI, Moyé LA, Simari RD, Cardiovascular Cell Therapy Research Network: LateTIME: a phase II, randomized, double-blinded, placebo-controlled pilot trial evaluating the safety and effect of administration of bone marrow mononuclear cells 2 to 3 weeks after acute myocardial infarction. Tex Heart Inst J 2010;37:412-420.

\$ Sürder D, Schwitter J, Moccetti T, Astori G, Rufibach K, Plein S, Lo Cicero V, Soncin S, Windecker S, Moschovitis A, Wahl A, Erne P, Jamshidi P, Auf der Mauer C, Manka R, Soldati G, Buhler I, Wyess C, Landmesser U, Lüscher TF, Corti R: Cell-based therapy for myocardial repair in patients with acute myocardial infarction: Rationale and study design of the SWiss multicenter Intracoronary Stem cells Study in Acute Myocardial Infarction (SWISS-AMI). Am Heart J 2010; 160:58-64.
10 Hinkel R, El-Aouni C, Olson T, Horstkotte J, Mayer S, Müller S, Willhauck M, Spitzweg C, Gildehaus FJ, Münzing W, Bock-Marquette I, DiMaio M, Hatzopoulos AK, Boekstegers P, Kupatt C: Thymosin $\beta 4$ is an essential paracrine factor of embryonic endothelial progenitor cell mediated cardioprotection. Circulation 2008;117:2232-2240.

11 Joggerst SJ, Hatzopoulos AK: Stem cell therapy for cardiac repair: benefits and barriers. Exp Rev Mol Med 2009;11:e20.

12 Zhang M, Mal N, Kiedrowski M, Chacko M, Askari AT, Popovic ZB, Koc ON, Penn MS: SDF-1 expression by mesenchymal stem cells results in trophic support of cardiac myocytes after myocardial infarction. FASEB J 2007;21:3197-3207.

13 Matsumoto R, Omura T, Yoshiyama M, Hayashi T, Inamoto S, Koh K-R, Ohta K, Izumi Y, Nakamura Y, Akioka K, Kitaura Y, Takeuchi K, Yoshikawa J: Vascular endothelial growth factor-expressing mesenchymal stem cell transplantation for the treatment of acute myocardial infarction. Arterioscler Thromb Vasc Biol 2005;25:1168-1173.

14 Cheng Z, Ou L, Zhou X, Li F, Jia X, Zhang Y, Liu X, Li Y, Ward CA, Melo LG, Kong D: Targeted migration of mesenchymal stem cells modified with CXCR4 gene to infarcted myocardium improves cardiac performance. Mol Ther 2008;16:571-579.

15 Huang J, Zhang Z, Guo J, Ni A, Deb A, Zhang L, Mirotsou M, Pratt RE, Dzau VJ: Genetic modification of mesenchymal stem cells overexpressing CCR1 increases cell viability, migration, engraftment, and capillary density in injured myocardium. Circ Res 2010; 106:1753-1762. 